\title{
Artificial neural network model for simulation of water distribution in sprinkle irrigation
}

\author{
Paulo L. de Menezes ${ }^{1}$, Carlos A. V. de Azevedo², Eduardo Eyng ${ }^{3}$, José Dantas Neto² \& Vera L. A. de Lima² \\ ${ }^{1}$ Núcleo de Ciência da Computação/Universidade Tecnológica Federal do Paraná. Medianeira, PR. E-mail: plopes@utfpr.edu.br (Autor correspondente) \\ ${ }^{2}$ Unidade Acadêmica de Engenharia Agrícola/Universidade Federal de Campina Grande. Campina Grande, PB. E-mail: cazevedo@deag.ufcg.edu.br; \\ zedantas1955@gmail.com; antuneslima@gmail.com \\ ${ }^{3}$ Núcleo de Ciências Biológicas e Ambientais/Universidade Tecnológica Federal do Paraná. Medianeira, PR. E-mail: eduardoeyng@utfpr.edu.br
}

\section{Key words:}

sprinkler

water distribution uniformity

artificial intelligence

computational model

\begin{abstract}
A B S T R A C T
Determining uniformity coefficients of sprinkle irrigation systems, in general, depends on field trials, which require time and financial resources. One alternative to reduce time and expense is the use of simulations. The objective of this study was to develop an artificial neural network (ANN) to simulate sprinkler precipitation, using the values of operating pressure, wind speed, wind direction and sprinkler nozzle diameter as the input parameters. Field trials were performed with one sprinkler operating in a grid of $16 \times 16$, collectors with spacing of $1.5 \mathrm{~m}$ and different combinations of nozzles, pressures, and wind conditions. The ANN model showed good results in the simulation of precipitation, with Spearman's correlation coefficient $\left(r_{s}\right)$ ranging from 0.92 to 0.97 and Willmott agreement index $(d)$ from 0.950 to 0.991 , between the observed and simulated values for ten analysed trials. The ANN model shows promise in the simulation of precipitation in sprinkle irrigation systems.
\end{abstract}

\section{Palavras-chave:}

aspersor

uniformidade de distribuição de água

inteligência artificial

modelo computacional

\section{Modelo em redes neurais artificiais para a simulação da precipitação na irrigação por aspersão}

\begin{abstract}
R E S U M O
A determinação dos coeficientes de uniformidade de distribuição da água dos sistemas de irrigação por aspersão depende, em geral, de ensaios em campo que envolvem tempo e recursos financeiros. Uma alternativa para reduzir custo e tempo é a utilização de simulações. Objetivou-se, com este trabalho, o desenvolvimento de um modelo em redes neurais artificiais (RNA) para simular a precipitação de um aspersor cujos parâmetros de entrada são os valores de pressão de operação, velocidade do vento, direção do vento e diâmetro do bocal do aspersor. Ensaios foram feitos em campo com um aspersor operando em uma malha de $16 \times 16$ coletores com espaçamento de $1,5 \mathrm{~m}$ e diferentes combinações de bocais, pressões e condições de vento. O modelo RNA apresentou bons resultados na simulação da precipitação com correlação de Spearman $\left(r_{s}\right)$ entre os dados obtidos em ensaio de campo e os dados simulados, apresentando valores entre 0,92 e 0,97 e índice de concordância de Willmott (d) entre 0,950 e 0,991 para dez ensaios analisados. O modelo RNA mostrou-se promissor na simulação da precipitação em sistemas de irrigação por aspersão.
\end{abstract}




\section{INTRODUCTION}

In order to ensure and improve crop yield, the technique of irrigation has been used as a complement or a substitute of natural rainfall, so as to guarantee that the water demand is met.

Among the existing irrigation systems, sprinkle irrigation is one of the most used, since it can adapt to the diversities of soil, topography, crop and the size of the area to be cultivated, which allows a good control of the applied water depth and consequently of its efficiency.

In order to reduce costs and the waste of water and time in the evaluation of sprinkle irrigation systems, simulations can be used to predict the behavior and the results of irrigation.

Many researchers have studied the importance of simulations, such as Faria et al. (2012), who evaluated the applicability of a semiempirical model of Richards \& Weatherhead for trials under different wind conditions, and Oliveira et al. (2009), who evaluated the hypothesis of the existence of a linear relationship between the radius of throw of a gun type sprinkler and wind speed.

In the context of the simulations, it is possible to use artificial neural networks (ANNs), which are computational models inspired in the neural structure of intelligent organisms, neurons and synapses, that acquire knowledge through experience. The most important property of ANNs is the ability to learn through examples, by adjusting the weights of the connections between neurons.

ANNs can be applied in many areas, like soil digital mapping based on soil-landscape relationships (Arruda et al., 2013), classification of degradation levels of pastures (Chagas et al., 2009), rainfall erosivity (Moreira et al., 2006), estimation of reference evapotranspiration through air temperature data (Alves Sobrinho et al., 2011), modeling of soil penetration resistance (Santos et al., 2012) or even identification and classification of soybean cultivars by planting region (Galão et al., 2011).

In this context, this study proposed the development of a multilayer perceptron (MLP) neural network model for the simulation of the precipitation of a sprinkler.

\section{Material AND Methods}

The ANN model was trained and validated using results from field trials at the Ouro Verde Farm, located in the municipality of Medianeira-PR, Brazil (25 $12^{\prime} 19.26^{\prime \prime} \mathrm{S}$; $54^{\circ} 3^{\prime} 27.93^{\prime \prime} \mathrm{W} ; 360 \mathrm{~m}$ ), in order to characterize the spatial distribution of water applied by a sprinkler (Pingo Giro Completo - Fabrimar), operating with different combinations of nozzles, operating pressure, wind speed and wind direction.

The sprinkler was installed at $1.25 \mathrm{~m}$ from the soil surface with water nozzle at a vertical distance of $0.60 \mathrm{~m}$ from the collectors. In total, 256 pluviometers were installed from the center of the irrigated area $(24 \times 24 \mathrm{~m})$, at a regular spacing of $1.5 \times 1.5 \mathrm{~m}$ in both coordinate directions. Figure 1 shows the coordinate system $(\mathrm{X}, \mathrm{Y})$ adopted in the trials and the notation of the angle $\Phi$, which describes the predominant wind direction in relation to the lines of the water collectors used in the field trials. Two kits for water distribution uniformity trials (Fabrimar') were used, which consisted of: 300 pluviometers

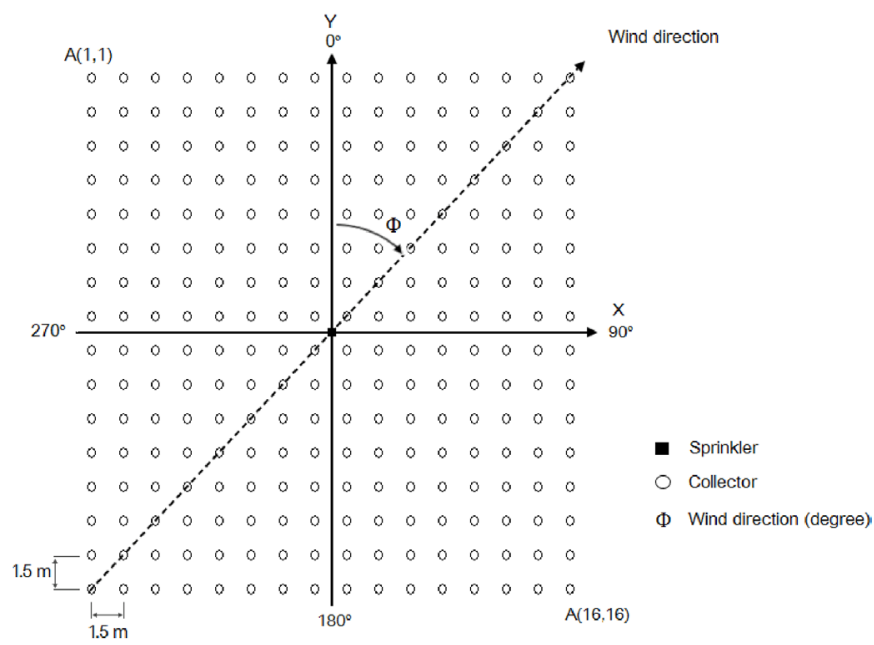

Figure 1. Scheme of the collection grid and wind direction

made of engineering plastic for water collection; 10 graduated cylinders made of transparent thermoplastic, with scale of 0.5 $\mathrm{mm}$, from 0 to $15 \mathrm{~mm} ; 300$ bars made of structural aluminum, for the support and fixation of the collectors on the ground.

The operating pressure of each test was controlled using a vertical, glycerin-filled Bourdon tube pressure gauge, with scale of up to $981 \mathrm{kPa}$, attached to the base of the sprinkler and another one with scale of up to $686 \mathrm{kPa}$ at the beginning of the mainline. The pressure was regulated through a gate valve and the operation time controlled using a digital stopwatch (Casio $\left.{ }^{\circ}\right)$

Wind speed and wind direction were automatically recorded by a weather station (Davis Vantage Vue), at regular intervals of $5 \mathrm{~min}$, at $2 \mathrm{~m}$ from the soil and at a distance of 25 $\mathrm{m}$ from the irrigated area. Precipitation measurements were recorded in worksheets, in the form a $16 \times 16$ matrix, referred to as "A".

Nine combinations of nozzles $(2.6 \times 2.4 ; 2.8 \times 2.4 ; 3.0 \times$ $2.6 ; 3.2 \times 2.6 ; 3.4 \times 2.6 ; 3.6 \times 2.8 ; 3.8 \times 2.8 ; 4.0 \times 2.8$ and 4.0 $\mathrm{x} 3.2 \mathrm{~mm}$ ) were tested at the four pressure values suggested by the manufacturer $(196,245,294$ and $343 \mathrm{kPa})$. Since the number of samples necessary for the training of a neural network is unknown (Másson, 1990) and the possibility of success increases as the number of samples increases, three trials were performed for each combination. However, these trials were not three replicates, because wind speed and wind direction changed according to the field conditions during each trial. Thus, 108 trials were conducted, each one with duration of $2 \mathrm{~h}$.

The body of the artificial neuron consisted of a sum function (linear combiner $\Sigma$ ), represented by the weighted sum of the values received by the neuron through the synapses and summed to the bias value that is externally applied and has the effect of increasing or decreasing the output value $\left(\mathrm{v}_{\mathrm{k}}\right)$ of the body of the neuron (Haykin, 2001). This value generated in the body of the neuron $\left(\mathrm{v}_{\mathrm{k}}\right)$ passes through an activation function $\varphi($.$) , which restricts the output amplitude of the neuron and$ generates an output value $\left(\mathrm{y}_{\mathrm{k}}\right)$, which represents the net output value of the neuron and will be transmitted to the subsequent neuron, simulating the flow of impulses in the brain.

The neuron can be mathematically described by Eqs. 1 and 2 (Haykin, 2001): 


$$
\mathrm{v}_{\mathrm{k}}=\sum_{\mathrm{j}=0}^{\mathrm{m}} \mathrm{w}_{\mathrm{kj}} \cdot \mathrm{x}_{\mathrm{j}}+\mathrm{b}_{\mathrm{k}}
$$

and,

$$
\mathrm{y}_{\mathrm{k}}=\varphi\left(\mathrm{v}_{\mathrm{k}}\right)
$$

where:

$\mathrm{v}_{\mathrm{k}} \quad$ - induced local field of the neuron;

$\mathrm{y}_{\mathrm{k}} \quad$ - output signal of the neuron $\mathrm{k}$;

$\mathrm{x}_{0}, \mathrm{x}_{1}, \mathrm{x}_{2}, \ldots, \mathrm{x}_{\mathrm{m}}$ - input signals;

$\mathrm{w}_{\mathrm{k} 1}, \mathrm{w}_{\mathrm{k} 2}, \mathrm{w}_{\mathrm{k} 3}, \ldots, \mathrm{w}_{\mathrm{km}}$ - synaptic weights of the neuron $\mathrm{k}$;

$\mathrm{b}_{\mathrm{k}} \quad$ - bias applied to the neuron $\mathrm{k}$; and

$\varphi($.$) - activation function.$

A multilayer perception neural network was developed and validated, trained with the backpropagation algorithm, a feedforward function and a sigmoid-type activation function, $\varphi($.$) , defined by Eq. 3$ (Haykin, 2001):

$$
\varphi(\mathrm{v})=\frac{1}{1+\mathrm{e}^{-\mathrm{av}}}
$$

where $\mathrm{a}$ is the parameter defining the slope of the function.

In this study, the dataset of the 108 trials was normalized in the interval from 0 to 1 , according to Chagas et al. (2010), and randomly divided into subsets: training subset data (98 trials) and validation subset data (10 trials); the latter was used for the discussion of the results of the model. As in Santos et al. (2012), the strategy of cross-validation was employed in this study, with $20 \%$ of the training data used to estimate the performance of the ANN and determine the moment to interrupt the training, in order to avoid excessive training.

For the parametrization, creation, training and validation of the topologies of the neural network in this study, since 31148 topologies of candidate networks were evaluated and the one with the best result was selected, four computational algorithms were developed and executed by the software for neural network simulation SNNS (Zell et al., 1996), in order to test networks with, respectively, one, two, three and four hidden layers.

The ten randomly selected trials for the validation subset were 13, 15, 41, 55, 56, 85, 88, 89, 93 and 100. Precipitation measurements and field conditions (combination of nozzles, operating pressure, wind speed and wind direction) in which these trials were performed are described below.
In this study, the agreement index (d) was used to compare the values predicted by the model with the observed values. According to Willmott (1981), this index varies from 0 (no agreement) to 1 (perfect agreement) and can be used to measure the accuracy between two models, as shown in Eq. 4.

$$
\mathrm{d}=1-\frac{\sum_{\mathrm{i}=1}^{\mathrm{n}}\left(\mathrm{E}_{\mathrm{i}}-\mathrm{O}_{\mathrm{i}}\right)^{2}}{\sum_{\mathrm{i}=1}^{\mathrm{n}}\left(\left|\mathrm{E}_{\mathrm{i}}-\mathrm{O}\right|+\left|\mathrm{O}_{\mathrm{i}}-\mathrm{O}\right|\right)^{2}}
$$

where:

$$
\begin{array}{ll}
\mathrm{E}_{\mathrm{i}} & \text { - values predicted by the model; } \\
\mathrm{O}_{\mathrm{i}} & \text { - observed values; and } \\
\mathrm{O} & \text { - mean of the observed values. }
\end{array}
$$

\section{Results AND Discussion}

The ANN with the best results was composed of one input layer with 4 neurons, one hidden layer with 280 neurons and the output layer with 256 neurons. The fact that the ANN with the best results has only one hidden layer agrees with the results observed by Soares et al. (2014), who estimated soil water retention using ANN, and Zanetti et al. (2008), who estimated reference evapotranspiration using ANNs and concluded that only one hidden layer is sufficient to represent the non-linear relationship between climatic elements and reference evapotranspiration.

According to the results of the analysis and the inferences on data distribution (Table 1), in the normality tests of Kolmogorov-Smirnov and Shapiro-Wilk for the ten trails used in the validation of the ANN model, considering 0.05 significance $(\alpha=0.05)$, the hypothesis that precipitation data follow normal distribution was rejected. The non-normality of the data is a consequence of the high frequency of values equal to zero, observed in the field trials.

At 0.05 level of significance, the Levene test accepts the hypothesis of homogeneity between observed and simulated data with p-value $>0.05$ for seven of the ten trials (Table 2). According to the test of Wilcoxon-Mann-Whitney ( $\alpha=0.05$ ) (Table 2), used to indicate whether the position measurements

\begin{tabular}{|c|c|c|c|c|c|c|}
\hline & \multicolumn{3}{|c|}{ Kolmogorov-Smirnov Test } & \multicolumn{3}{|c|}{ Shapiro-Wilk Test } \\
\hline & Statistics & $p$-value & Normal & Statistics & $p$-value & Normal \\
\hline Trial 56 & 0.175 & $3.33 \times 10^{-21}$ & $\mathrm{~N}$ & 0.855 & $9.16 \times 10^{-15}$ & $\mathrm{~N}$ \\
\hline Trial 15 & 0.230 & $3.33 \times 10^{-21}$ & $\mathrm{~N}$ & 0.782 & $3.66 \times 10^{-18}$ & $\mathrm{~N}$ \\
\hline Trial 13 & 0.270 & $3.33 \times 10^{-21}$ & $\mathrm{~N}$ & 0.709 & $7.68 \times 10^{-21}$ & $\mathrm{~N}$ \\
\hline Trial 55 & 0.155 & $3.33 \times 10^{-21}$ & $\mathrm{~N}$ & 0.881 & $2.75 \times 10^{-13}$ & $\mathrm{~N}$ \\
\hline Trial 100 & 0.201 & $3.33 \times 10^{-21}$ & $\mathrm{~N}$ & 0.836 & $9.35 \times 10^{-16}$ & $\mathrm{~N}$ \\
\hline Trial 88 & 0.190 & $3.33 \times 10^{-21}$ & $\mathrm{~N}$ & 0.831 & $5.08 \times 10^{-16}$ & $\mathrm{~N}$ \\
\hline Trial 41 & 0.176 & $3.33 \times 10^{-21}$ & $\mathrm{~N}$ & 0.873 & $8.91 \times 10^{-14}$ & $\mathrm{~N}$ \\
\hline Trial 93 & 0.215 & $3.33 \times 10^{-21}$ & $\mathrm{~N}$ & 0.834 & $7.33 \times 10^{-16}$ & $\mathrm{~N}$ \\
\hline Trial 89 & 0.232 & $3.33 \times 10^{-21}$ & $\mathrm{~N}$ & 0.837 & $9.89 \times 10^{-16}$ & $\mathrm{~N}$ \\
\hline Trial 85 & 0.208 & $3.33 \times 10^{-21}$ & $\mathrm{~N}$ & 0.837 & $9.93 \times 10^{-16}$ & $\mathrm{~N}$ \\
\hline
\end{tabular}
of the tested dataset come from similar populations, in eight of the ten trials the observed and simulated data come from similar populations (or the same population), reinforcing the hypothesis that the ANN expressed with good precision the characteristics of the training samples.

Table 1. Tests of adherence to normal distribution for the validation subset of precipitation data 
Table 2. Tests of homoscedasticity and population similarity between observed data and the values simulated by the ANN model

\begin{tabular}{lccccc}
\hline & \multicolumn{2}{c}{ Wilcoxon-Mann-Whitney Test } & & \multicolumn{2}{c}{ Levene Test } \\
\cline { 2 - 3 } \cline { 5 - 6 } & $\mathbf{W}$ & $\mathbf{p}$-value & & $\mathbf{F}$ & p-value \\
Trial 56 & 36025 & 0.050 & & 0.1945 & 0.659 \\
Trial 15 & 30225.5 & 0.121 & & 0.0035 & 0.953 \\
Trial 13 & 28634.5 & $0.011^{*}$ & & 0.2155 & 0.643 \\
Trial 55 & 28407.5 & $0.009^{*}$ & & 10.247 & $0.001^{*}$ \\
Trial 100 & 30547 & 0.183 & & 89.603 & $0.003^{*}$ \\
Trial 88 & 31969.5 & 0.629 & & 0.3833 & 0.536 \\
Trial 41 & 32537 & 0.889 & 0.2075 & 0.649 \\
Trial 93 & 31605 & 0.478 & 0.5733 & 0.449 \\
\hline Trial 89 & 28674.5 & $0.014^{*}$ & 3.0639 & 0.081 \\
Trial 85 & 32374 & 0.811 & 0.8904 & 0.346 \\
\hline *Rejected at 0.05 of significance & & & \\
\hline
\end{tabular}

Spearman's correlation test was performed for the 10 datasets used for the validation of the ANN model, which were not part of the training step and the parameter estimation. The $r_{s}$ correlation coefficients for the 10 trials used for model validation are shown in Table 3. A strong correlation was observed for all field trials, with $\mathrm{r}_{\mathrm{s}}$ ranging from 0.929 to 0.976 , an indication that the ANN model predicted values very close to those observed in the field trials.

The sprinkler precipitation observed in the field trial and the respective values simulated by the neural network for the Trial no 93 are shown in Figures 2A and 2B. The best results were observed for the ANN with duration of $2 \mathrm{~h}$, nozzle combination of $4.0 \times 2.8 \mathrm{~mm}$, operating pressure of $196 \mathrm{kPa}$, with mean wind speed of $0.74 \mathrm{~m} \mathrm{~s}^{-1}$ in the direction $325^{\circ}$.

The correlations between the observed and ANN-simulated data, with the respective Spearman's coefficients $\left(r_{s}\right)$ measuring correlation strength, are shown in Figures 3 to 5 . The dispersion between observed and simulated values for the Trial 93 is shown in Figure 3A. Strong correlation $\left(r_{s}=0.976\right)$ was observed between the two datasets (Table 3), which indicates good performance of the ANN model in the prediction of these precipitation values.

Table 3. Values of Spearman's correlation coefficient $\left(r_{c}\right)$ and Willmott agreement index $(d)$ between precipitation values observed and simulated by the neural network for the 10 field trials used in the model validation

\begin{tabular}{|c|c|c|c|c|c|c|}
\hline \multirow{2}{*}{ Trial No } & \multirow{2}{*}{$\begin{array}{l}\text { Nozzle } \\
(\mathrm{mm})\end{array}$} & \multirow{2}{*}{$\begin{array}{c}\text { Pressure } \\
(\mathrm{kPa})\end{array}$} & \multicolumn{2}{|c|}{ Wind } & \multirow[b]{2}{*}{$\mathbf{r}_{\mathrm{s}}$} & \multirow{2}{*}{ d } \\
\hline & & & Speed $\left(\mathrm{m} \mathrm{s}^{-1}\right)$ & Direction (degree) & & \\
\hline 13 & $2.8 \times 2.4$ & 196 & 0.70 & 76.50 & 0.929 & 0.950 \\
\hline 15 & $2.8 \times 2.4$ & 294 & 0.18 & 95.16 & 0.965 & 0.985 \\
\hline 41 & $3.2 \times 2.6$ & 196 & 0.79 & 116.76 & 0.965 & 0.988 \\
\hline 55 & $3.4 \times 2.6$ & 294 & 0.87 & 139.26 & 0.974 & 0.986 \\
\hline 56 & $3.4 \times 2.6$ & 343 & 0.33 & 245.70 & 0.956 & 0.977 \\
\hline 85 & $4.0 \times 2.8$ & 196 & 1.00 & 214.86 & 0.963 & 0.989 \\
\hline 88 & $4.0 \times 2.8$ & 343 & 1.23 & 246.60 & 0.952 & 0.991 \\
\hline 89 & $4.0 \times 2.8$ & 196 & 1.29 & 94.92 & 0.951 & 0.975 \\
\hline 93 & $4.0 \times 2.8$ & 196 & 0.75 & 271.80 & 0.976 & 0.988 \\
\hline 100 & $4.0 \times 3.2$ & 343 & 0.34 & 152.28 & 0.967 & 0.986 \\
\hline
\end{tabular}

A.

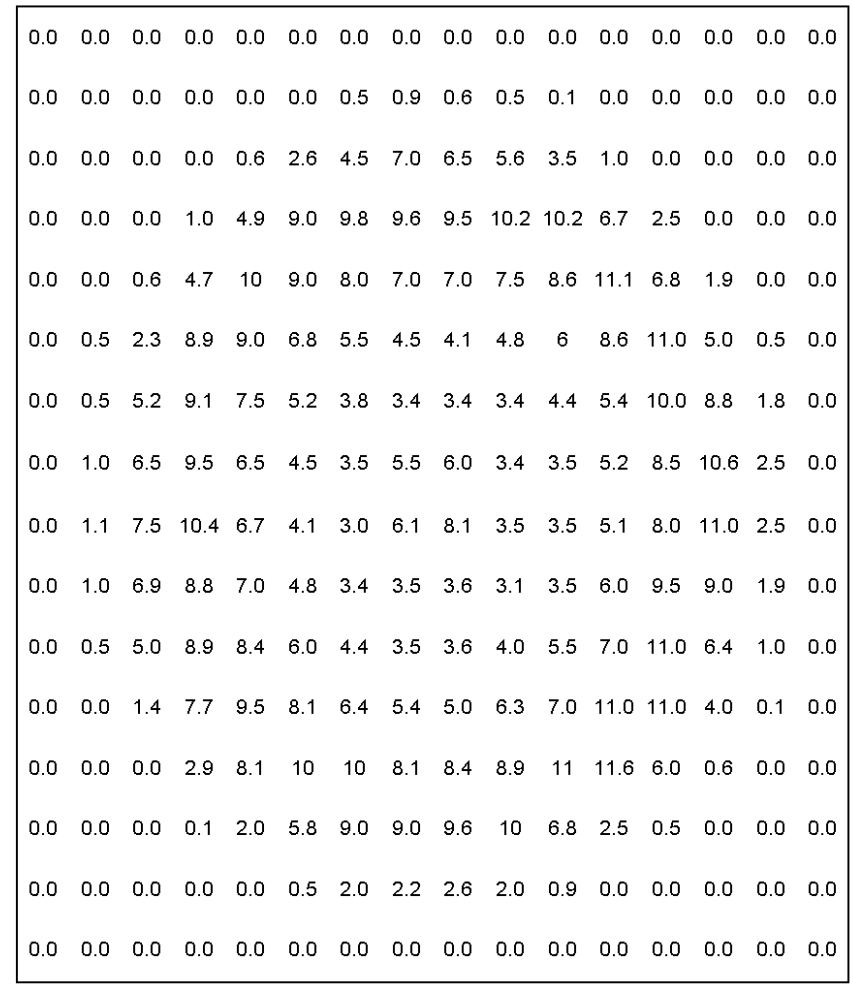

B.

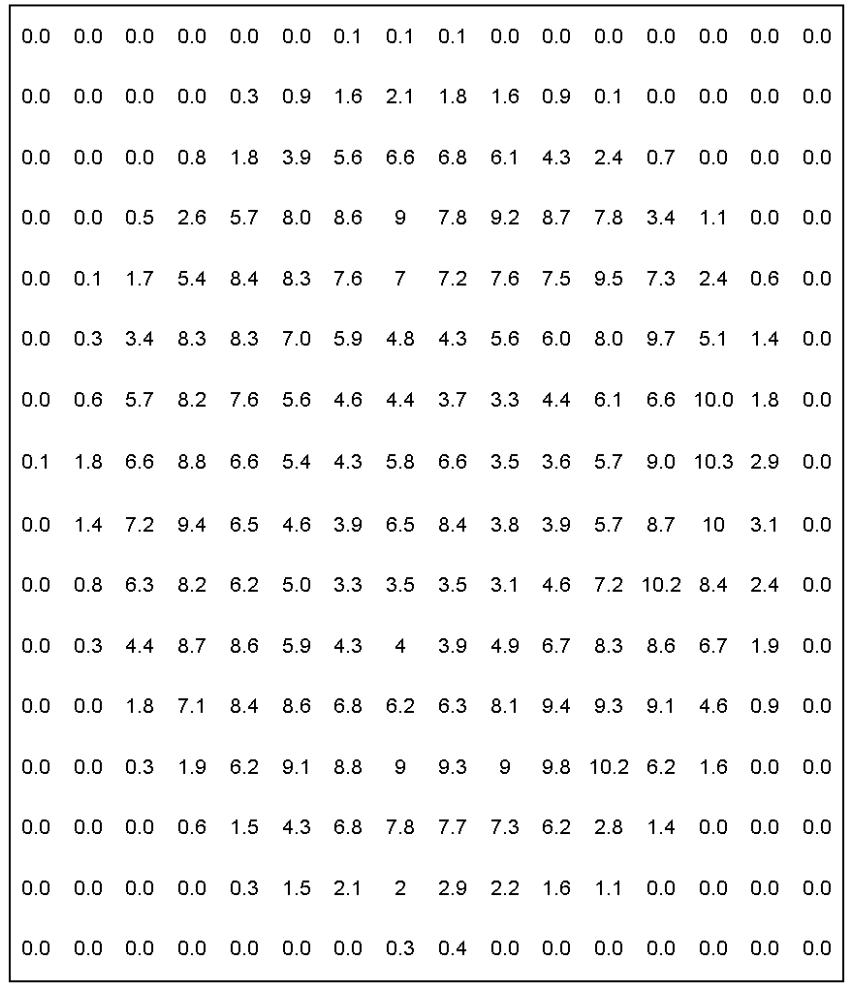

Figure 2. Sprinkler precipitation for the best correlation coefficient, $r_{s}=0.976$, in the Trial 93: observed data (A) and ANN-simulated data (B) 

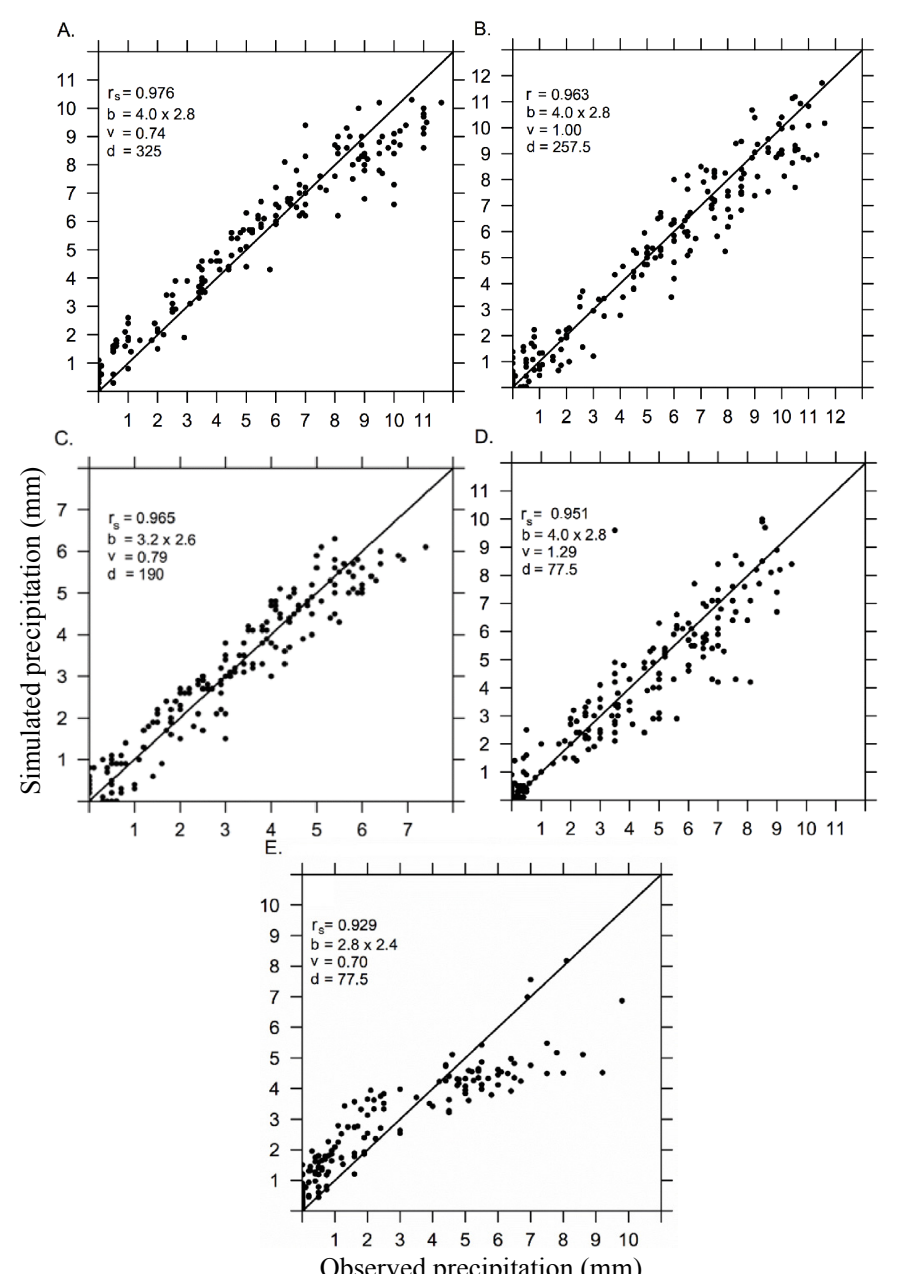

$r_{s}$ - correlation coefficient; $b$ - nozzle combination $(\mathrm{mm} \times \mathrm{mm}) ; \mathrm{v}$ - wind speed $\left(\mathrm{m} \mathrm{s}^{-1}\right) ; \mathrm{d}$ - wind direction (degree)

Figure 3. Correlation between observed and simulated precipitation for the operating pressure of $196 \mathrm{kPa}$, in the Trials 93 (A), 85 (B), 41(C), 89 (D) and $13(\mathrm{E})$

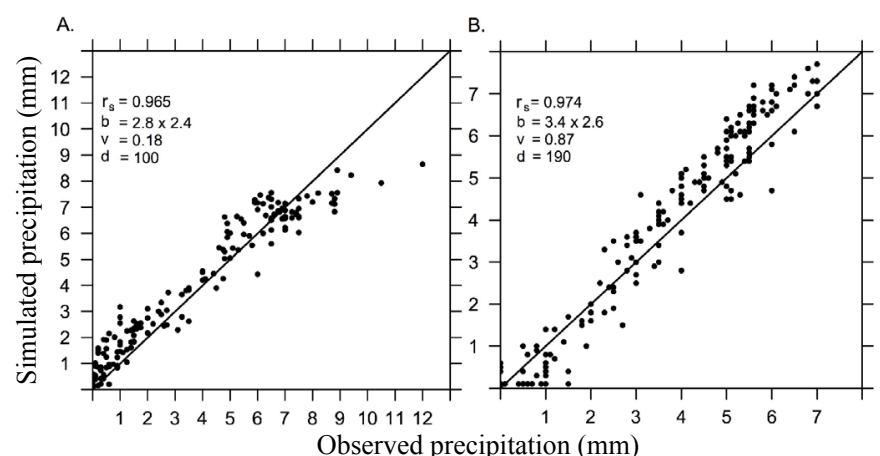

$r_{s}$ - correlation coefficient; $b$ - nozzle combination $(\mathrm{mm} \times \mathrm{mm}) ; \mathrm{v}$ - wind speed $\left(\mathrm{m} \mathrm{s}^{-1}\right) ; \mathrm{d}$ - wind direction (degree)

Figure 4. Correlation between observed and simulated precipitation for two ANN validation trials with duration of $2 \mathrm{~h}$ and operating pressure of $294 \mathrm{kPa}$ : Trial 15 (A) and Trial 55 (B)

The correlations indicate that, although the ANN was more precise in the prediction of the Trial 93 with operating pressure of $196 \mathrm{kPa}$, it also showed good fit for the other pressures.

\section{Conclusions}

1. The artificial neural network (ANN) developed to simulate the precipitation of the sprinkler was a multilayer

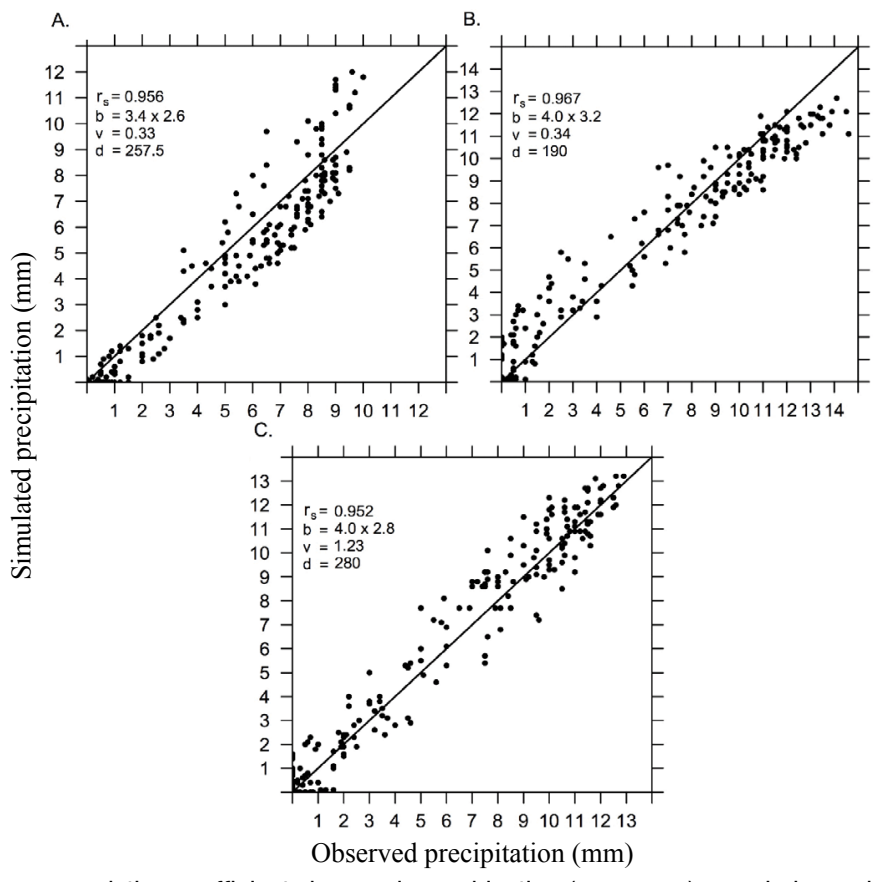

$r_{s}$ - correlation coefficient; $b$ - nozzle combination $(\mathrm{mm} \times \mathrm{mm}) ; \mathrm{v}$ - wind speed $\left(\mathrm{m} \mathrm{s}^{-1}\right) ; \mathrm{d}$ - wind direction (degree)

Figure 5. Correlation between observed and simulated precipitation for three ANN validation trials with duration of $2 \mathrm{~h}$ and operating pressure of $343 \mathrm{kPa}$ : Trial 56 (A), Trial 100 (B) and Trial 88 (C)

perceptron (MLP) model and the best topology was composed of 4 neurons in the input layer, only one hidden layer with 280 neurons and output layer with 256 neurons.

2. For the ten field trials used in its validation, the ANN model showed satisfactory performance in the prediction of sprinkler precipitation, with correlation coefficient, $r_{s}$, ranging from 0.929 to 0.976 and Willmott agreement index, $\mathrm{d}$, from 0.950 to 0.991 .

3. The ANN topology selected and tested in this study showed good performance in the prediction of sprinkler precipitation and the potential of these models for irrigation simulations.

4. The satisfactory performance was partially due to the high capacity of adaptation of the backpropagation learning algorithm.

\section{Literature Cited}

Alves Sobrinho,T.; Rodrigues, D. B. B.; Oliveira, P. T. S.; Rebucci, L. C. S.; Pertussatti, C. A. Estimativa da evapotranspiração de referência através de redes neurais artificiais. Revista Brasileira de Meteorologia, v.26, p.197-203, 2011. http://dx.doi.org/10.1590/ S0102-77862011000200004

Arruda, G. P.; Dematte, J. A. M.; Chagas, C. S. Mapeamento digital de solos por redes neurais artificiais com base na relação solopaisagem. Revista Brasileira de Ciências do Solo, v.37, p.327-338, 2013. http://dx.doi.org/10.1590/S0100-06832013000200004

Chagas, C. S.; Fernandes Filho, E. I.; Vieira, C. A. O.; Schaefer, C. E. G. R.; Carvalho Júnior, W. Atributos topográficos e dados do Landsat7 no mapeamento digital de solos com uso de redes neurais. Pesquisa Agropecuária Brasileira, v.45, p.497-507, 2010. http://dx.doi.org/10.1590/S0100-204X2010000500009 
Chagas, C. S.; Vieira, C. A. O.; Fernandes Filho, E. I.; Carvalho Junior, W. Utilização de redes neurais artificiais na classificação de níveis de degradação em pastagens. Revista Brasileira de Engenharia Agrícola e Ambiental, v.13, p.319-327, 2009. http://dx.doi. org/10.1590/S1415-43662009000300014

Faria, L. C.; Beskow, S.; Colombo, A.; Oliveira, H. F. E. Modelagem dos efeitos do vento na uniformidade da irrigação por aspersão: Aspersores de tamanho médio. Revista Brasileira de Engenharia Agrícola e Ambiental v.16, p.133-141, 2012. http://dx.doi. org/10.1590/S1415-43662012000200002

Galão, O. F.; Borsato, D; Pinto, J. P.; Visentainer, J. V.; CarrãoPanizzi, M. C. Artificial neural networks in the classification and identification of soybean cultivars by planting region. Journal of the Brazilian Chemical Society, v.22, p.142-147, 2011. http:// dx.doi.org/10.1590/S0103-50532011000100019

Haykin, S. Redes neurais: Princípios e prática. 2.ed. Porto Alegre: Bookman, 2001. 900p.

Másson, E; Wang Y. Introduction to computation and learning in artificial neural networks. European Journal of Operational Research, v.47, p.1-28, 1990. http://dx.doi.org/10.1016/0377-2217(90)90085-P

Moreira, M. C.; Cecilio, R. A.; Pinto, F. A. C.; Pruski, F. F. Desenvolvimento e análise de uma rede neural artificial para estimativa da erosividade da chuva para o Estado de São Paulo. Revista Brasileira de Ciência do Solo, v.30, p.1069-1076, 2006. http://dx.doi.org/10.1590/S0100-06832006000600016
Oliveira, H. F. E.; Colombo, A.; Faria, L. C. Modelagem dos efeitos do vento sobre as dimensões do alcance do jato de um canhão hidráulico. Revista Brasileira de Engenharia Agrícola e Ambiental, v.13, p.818-824, 2009. http://dx.doi.org/10.1590/ S1415-43662009000700002

Santos, F. L.; Jesus, V. A. M.; Valente, D. S. M.. Modeling of soil penetration resistance using statistical analyses and artificial neural networks. Acta Scientiarum Agronomy, v.34, p.219-224, 2012. http://dx.doi.org/10.4025/actasciagron.v34i2.11627

Soares, F. C.; Robaina, A. D.; Peiter, M. X.; Russi, J. L.; Vivian, G. A. Redes neurais artificiais na estimativa da retenção de água do solo. Ciência Rural, v.44, p.293-300, 2014. http://dx.doi.org/10.1590/ S0103-84782014000200016

Willmott, C. J.; On the validation of models. Physical Geography, v.2, p.184-194, 1981.

Zanetti, S. S.; Sousa, E. F.; Carvalho, D. F.; Bernardo, S. Estimação da evapotranspiração de referência no Estado do Rio de Janeiro usando redes neurais artificiais. Revista Brasileira de Engenharia Agrícola e Ambiental, v.12, p.174-180, 2008. http://dx.doi. org/10.1590/S1415-43662008000200010

Zell, A.; Mamier, G.; Vogt, M.; Mache, N.; Hubner, R.; Doring, S.; Herrmann, K.; Soyez, T.; Schmalzl, M.; Sommer, T.; Hatzigeorgiou, A.; Posselt, D.; Schreiner, T.; Kett, B.; Clemente, G.; Wieland, J.; Gatter, J. Stuttgart neural network simulator: User manual Version 4.2. Stuttgart: University of Stuttgart, 1996. 338p. 